DOI: $10.24326 /$ fmpmsa.2017.27

\title{
THE EFFECT OF DIESEL FUEL TEMPERATURE, SPEED AND LOAD ON SOME PERFORMANCE PARAMETERS OF TRACTOR ENGINE
}

\author{
Naseer Salman KADHIM ${ }^{1}$, Salim M. IDHAS ${ }^{2}$ \\ ${ }^{1}$ University of Baghdad, College of Agriculture, Department of agricultural machines and equipment, \\ Baghdad, IRAQ \\ ${ }^{2}$ Ministry of Agriculture, Baghdad, IRAQ \\ Email of corresponding author: dr.naseer@coagri.uobaghdad.edu.iq; drnaseeriq@gmail.com
}

Keywords: diesel fuel, fuel consumption FC, exhaust gas temperature EGT, noise intensity dB

\begin{abstract}
An experiment was conducted to study the effect of inlet fuel temperature on the performance of diesel engine for tractor (Anter-71). The experiment was carried out during June, 2014 in College of Agriculture, University of Baghdad. Three levels of diesel fuel temperature 40,45 , and $50^{\circ} \mathrm{C}$, and two levels of load (without load and with load), with variant engine speeds $(1000,1500,2000 \mathrm{rpm})$ were used as factors. Engine performance that was studied included fuel consumption FC, exhaust gas temperature EGT and noise intensity were measured at different fuel temperatures and loads. Treatment data were analyzed by using (SAS 2000) statistical program, factorial design under Complete Randomized Design (CRD), with three replications and Least Significant Differences LSD; 5\% were used. Results obtained showed that changing fuel temperature from $50^{\circ} \mathrm{C}$ to $45^{\circ} \mathrm{C}$ and $40{ }^{\circ} \mathrm{C}$ led to a significant reduction in fuel consumption, exhaust gas temperature and noise intensity. A comparison between working tractor engine with load and without load showed that loading tractor engine led to significant increase on FC, EGT, and noise intensity.
\end{abstract}

\section{INTRODUCTION}

Diesel engines generally draw more fuel than is needed for the combustion process, the excess fuel drawn is designed to cool and lubricate the engine fuel system. Mamat et al. (2009) mentioned that after circulation through the engine, fuel is returned to the fuel tank, this "returns" fuel, if untreated, will carry heat rejected by the fuel system and can over an extended run period and elevate the temperature of the fuel stored in the tank. Therefore as inlet temperature exceed $\left(37.8^{\circ} \mathrm{C}\right)$, fuel density and lubricity decrease, so diesel fuel expands slightly in volume and its temperature increases like all liquids. Pedley et al. (1989) showed that thermal expansion for diesel fuel coefficient equal to 0.00083 liter per Celsius degree and engine power can de-rate as much as $1 \%$ for every $5.6{ }^{\circ} \mathrm{C}$ in fuel temperature increasing. At approximately $73{ }^{\circ} \mathrm{C}$ some engines are automatically shut down by their protection systems, since diesel fuel provides cooling for the Injection system, the temperature of the fuel may vary considerably due to engine operating temperature. As fuel temperature increased, fuel density and viscosity were decreased, along with the lubrication capabilities of the fuel. There are many apparatuses and devices or methods were used to control the inlet and outlet fuel temperature for diesel engine. Chyo et al. (2011) were gained a patent by designing an apparatus to cool the fuel by fan and controlling the coolant pump. Rafidah (2012) reported that, most engine manufactures specify a maximum inlet fuel temperature to allow a full output rating. Aworanti et al. (2012) showed that as fuel temperature increased, the fuel density would be decreased that led to increase fuel consumption. Due to, higher injection pressure is required to gain an equal fuel mass in order to produce the same required brake power, that cause to increase engine fuel consumption. Oluwa Funmilayo (2012) defined load as external resistance which specify engine is subjected in practical engine operation, to produce useful work, Pawan (2009) also observed an increase in fuel consumption with present of load, engine running with load consumed more fuel than 
running without load, due to increasing in the external load caused an increase in the amount of power required to do same work, in order to overcome resistance due to external load. This needs more fuel consumption per time. Mohanty (2007) mentioned that external load would increase engine friction power. That increased the external resistance on the engine, led to increase the amount of power required to do the same work therefore more operating of the engine and thus more combustion of the fuel per unit time. hence load cause to influence of engine parameters, such as engine friction power which represent the difference between the indicated power (power at piston top as produced by the combustion gases) and the brake power (useful power) which available at the output engine shaft. Velmoragan and Gowthamn (2012) showed that clear increase in exhaust gas temperature with the load. Engine running with load recorded higher exhaust gas temperature than running without load, because with increasing the external load, the temperature of combustion chamber increases due to more fuel quantity is burned and thus resulting in higher cylinder wall temperature, consequently increasing of exhaust gas temperature. The aim of this research is to study the effect of fuel temperature, speed and loads on some of engine performance by controlling the temperature of fuel entering the engine.

\section{MATERIALS AND METHODS}

The conventional pure diesel fuel supplied by Al- Dura Refinery Company was used in this research. The fuel analyzed to test its physical properties under selected temperatures in laboratories of Oil Training Institute- Baghdad. The results of fuel analysis were shown in table 1.

Table 1. Fuel analysis with variant temperature

\begin{tabular}{|c|c|c|}
\hline Test type & Results & ASTM test \\
\hline Viscosity @ 40 ${ }^{\circ} \mathrm{C} . c S t$ & 3.8 & D445 \\
\hline Viscosity @ 80 ${ }^{\circ} \mathrm{C} . c S t$ & 2.1 & D445 \\
\hline Cloud point ${ }^{\circ} \mathrm{C}$ & -2 & D2500 \\
\hline Pour point ${ }^{\circ} \mathrm{C}$ & -6.7 & D 97 \\
\hline Diesel index (min) & 50 & D287 \\
\hline Cetane Number (min) & 53 & D445 \\
\hline Specific gravity @ 35 ${ }^{\circ} \mathrm{C}$ & 0.821 & D287 \\
\hline Specific gravity @ 40 ${ }^{\circ} \mathrm{C}$ & 0.816 & D287 \\
\hline Specific gravity @ $45^{\circ} \mathrm{C}$ & 0.813 & D287 \\
\hline Specific gravity @ 50 ${ }^{\circ} \mathrm{C}$ & 0.810 & D287 \\
\hline
\end{tabular}

An apparatus for controlling diesel fuel temperature was fixed in the front of the radiator of tractor (Figure 1).

Fig. 1. Location of the apparatus:

1- Temperature sensor;

2\&3 - Thermometer;

4-Flow valve;

5- Mounted channel;

6-Radiator grid;

7-Mounted frame;

8- Scale fuel tank

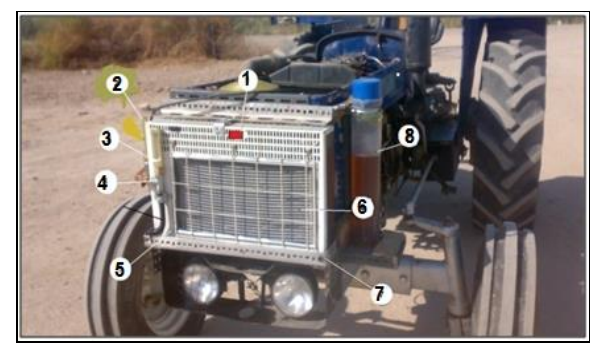

The parts of apparatus and experimental set up diagram showed in figure 2 and 3 respectively. 
Fertilizer sprayer implement disc type was used with the tractor to generate load on PTO shaft.

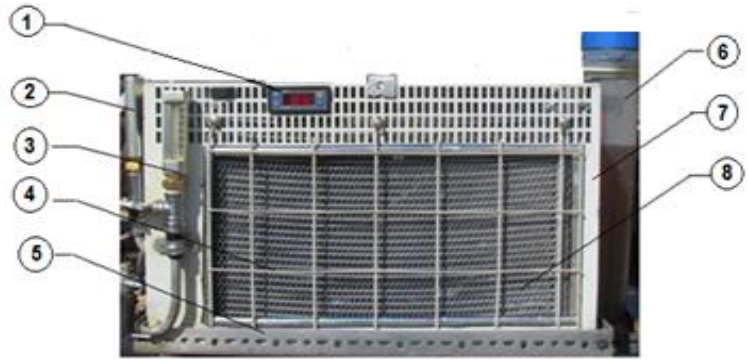

Fig.2. Parts of apparatus

1 -Temperature sensor 2-Inlet fuel thermometer

3-Outlet fuel thermometer 4-Radiator shield 5-Fixed

Frame 6-Scaled fuel tank 7-Radiators frame

8-Radiator core

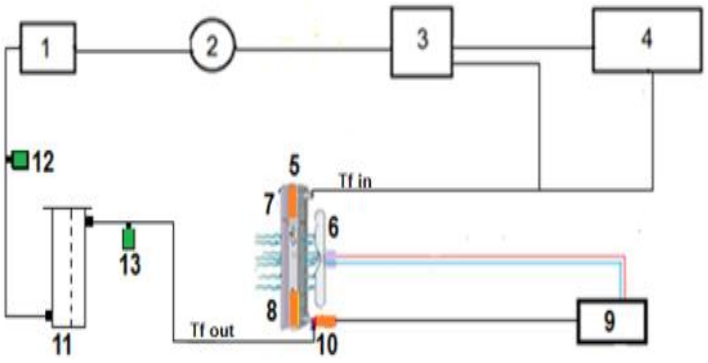

Fig 3. Schematic diagram of experimental setup 1-Preparing fuel pump 2-Fuel filter 3-Fuel injection pump 4-Engine 5-Radiator 6-DC fan (7, 8, 12, 13) Thermometers 9-Control unite 10-Temperature sensor 11-Scaled fuel tank.

\section{Test procedure}

Practically the factors of the experiment included, three levels of fuel temperature (40, 45, and $\left.50{ }^{\circ} \mathrm{C}\right)$. Three levels of engine speed $(1000,1500$ and $2000 \mathrm{rpm})$ and two levels of load (without load, and with load). Initially, scaled fuel tank (2 liters) must be filled with diesel fuel, run the engine for minimum 30 minutes on idle speed to warming up, then the engine speed was increased and fixed (by control lever) to $1000 \mathrm{rpm}$, setting fuel temperature control on $40{ }^{\circ} \mathrm{C}$. In that moment the fuel consumption was recorded manually which was determined by measuring the time $(t)$ was taking for the engine to consume a given volume of fuel, also the other parameters were registered which included, noise intensity and exhaust gas temperature by specific devices. Repeated the same test but with setting fuel temperature control on $45^{\circ} \mathrm{C}$ and followed the same steps that were done in the previous test and so that with setting fuel temperature at $50{ }^{\circ} \mathrm{C}$. Every test was repeated three times to be more accurate. All these tests were done without load and so that followed the same steps and engine speed $1500 \mathrm{rpm}$ and $2000 \mathrm{rpm}$ The same previous tests were done again by loading the tractor engine by engaging the fertilizer implement with PTO shaft. The fertilizer was filled with $100 \mathrm{~kg}$ of Urea $\mathrm{NH}_{3}$ and run the engine on $1000 \mathrm{rpm}$ with different fuel temperatures $\left(40,45\right.$, and $\left.50^{\circ} \mathrm{C}\right)$, and followed the same steps at engine speed $1500 \mathrm{rpm}$ and $2000 \mathrm{rpm}$ by the same above procedure. Every test was repeated three times at different times to be more accurate. Treatment data were analyzed by using (SAS 2000) statistical program, factorial design under Complete Randomized Design (CRD), with three replications and Least Significant Differences LSD; 5\% were used. Engine performance was analyzed by using the mathematical formulas.

\section{RESULTS AND DISCUSSION}

Figure 4 showed that the interaction between fuel temperature and speed has significant effect on FC. Fuel with low temperature $40^{\circ} \mathrm{C}$ and low speed $1000 \mathrm{rpm}$ recorded the lower rate 1.494 $\mathrm{kg} / \mathrm{h}$ of FC, and fuel with high temperature $50^{\circ} \mathrm{C}$ and high speed $2000 \mathrm{rpm}$ recorded the higher rate $4.506 \mathrm{~kg} / \mathrm{h}$ of FC. Figure 5 showed that the interaction between fuel temperature and load has a significant influence on FC. Fuel temperature $50^{\circ} \mathrm{C}$ recorded the higher rate of FC $3.096 \mathrm{~kg} / \mathrm{h}$ with load, while low fuel temperature $40^{\circ} \mathrm{C}$ recorded the lower rate of FC 
$2.533 \mathrm{~kg} / \mathrm{h}$ without load. Figure 6 represent the interaction between engine speed and load on fuel consumption FC. The higher rate of FC was $4.154 \mathrm{~kg} / \mathrm{h}$ recorded at higher speed 2000 $\mathrm{rpm}$ with load, and the lower rate of FC $1.566 \mathrm{~kg} / \mathrm{h}$ recorded at low speed $1000 \mathrm{rpm}$, without load. Figure 7 showed that the triple interaction between the fuel temperature, speed and load has a clear impact on the FC.

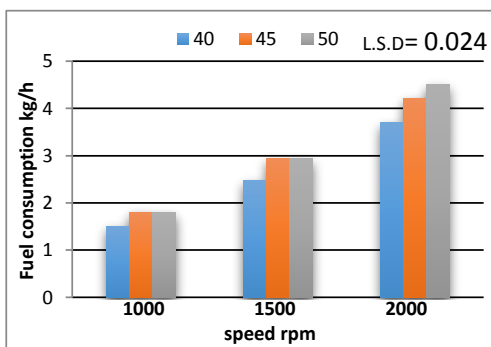

Fig.4. Effect of fuel temperature and Speed on FC

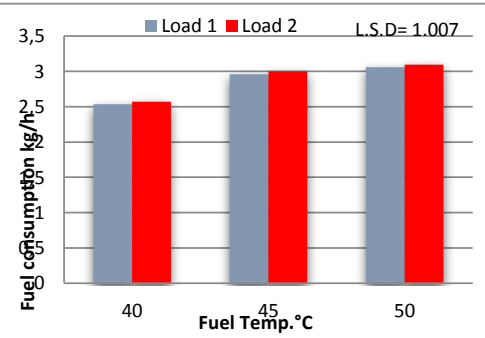

Fig 5. Effect of fuel temperature and load on FC

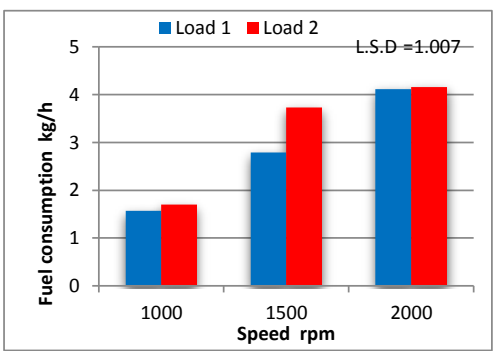

Fig 6. Effect of fuel engine speed and load on FC

The interaction between fuel temperature at $50^{\circ} \mathrm{C}$; with load and engine speed of 2000rpm fuel consumption recorded was $4.526 \mathrm{~kg} / \mathrm{h}$. With fuel temperature level $40^{\circ} \mathrm{C}$, the lower rate $1.479 \mathrm{~kg} / \mathrm{h}$ of FC without load and lowest speed was recorded. It can be noticed that effect of fuel temperature has more influence than other factors.

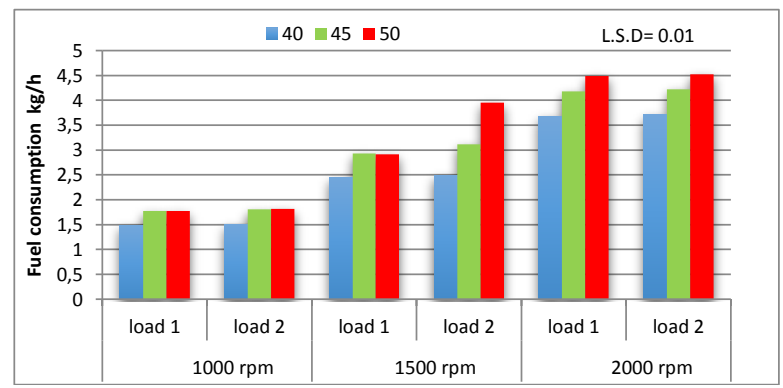

Fig. 7. The effect of triple interaction between fuel temperature, Speed and load on fuel consumption.

Figure 8 illustrated the interaction between fuel temperatures and speeds on EGT. Fuel at $40^{\circ} \mathrm{C}$ and $1000 \mathrm{rpm}$ speed was recorded the lowest rate $124^{\circ} \mathrm{C}$ of EGT, while fuel at $50^{\circ} \mathrm{C}$ with 2000rpm speed recorded the higher rate $151.5^{\circ} \mathrm{C}$ of EGT. Figure 9 showed that the interaction between fuel temperature and load has a significant effect on EGT. The highest rate $151.3^{\circ} \mathrm{C}$ of EGT was recorded when using fuel temperature at $50^{\circ} \mathrm{C}$ and with load while the lowest rate $124.3^{\circ} \mathrm{C}$ of temperature was registered when fuel temperature at $40^{\circ} \mathrm{C}$ and without load. Figure 10 showed a significant interaction between speed and load on EGT. The higher rate $162^{\circ} \mathrm{C}$ of EGT was recorded at $2000 \mathrm{rpm}$ with load and the lower rate $125^{\circ} \mathrm{C}$ of EGT was recorded the interaction between $1000 \mathrm{rpm}$ and without load. 


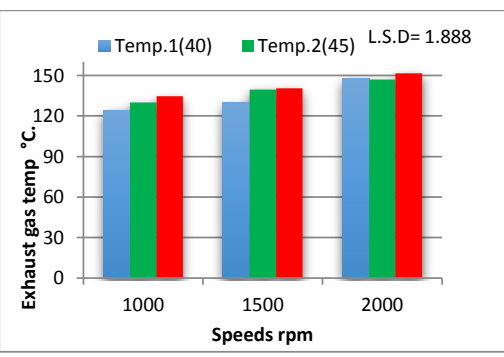

Fig. 8. Effect of fuel temperature and Speed on EGT

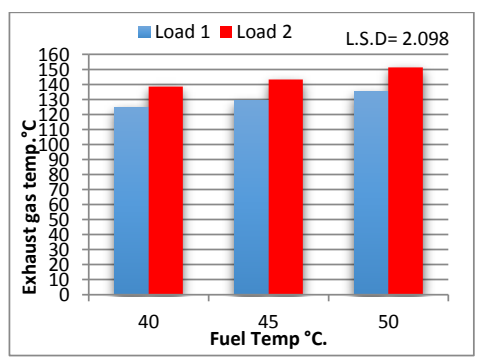

Fig. 9. Effect of fuel temperature and Speed on EGT

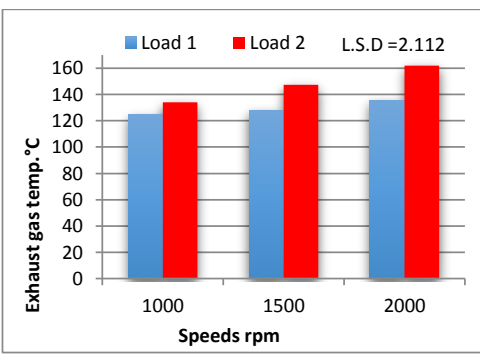

Fig. 10. Effect of speed and load on EGT

Figure 11 showed the triple interaction between fuel temperatures, speeds and load on EGT. The higher rate of EGT was $165^{\circ} \mathrm{C}$ which recorded, with fuel temperature at $50^{\circ} \mathrm{C}$, and speed of $2000 \mathrm{rpm}$ and with load and the lower rate $118^{\circ} \mathrm{C}$ of temperature which was recorded at $40^{\circ} \mathrm{C}$ and, $1000 \mathrm{rpm}$ and without load. It can be noticed that effect of engine speed has more influence than other factors.

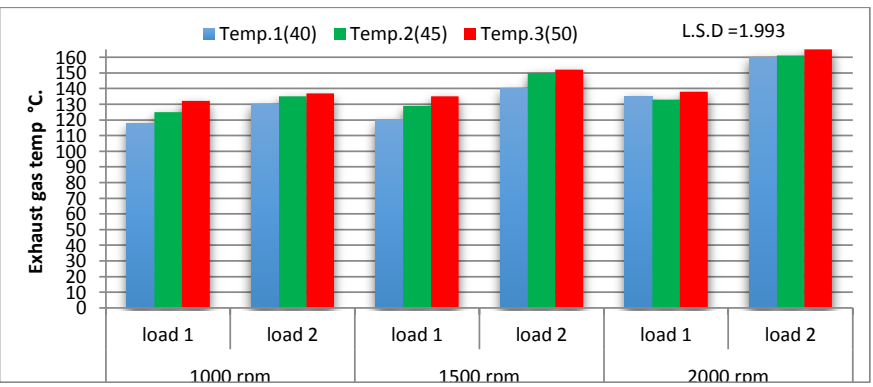

Fig.11. The effect of triple interaction between fuel temperature, Speed and load on EGT

Figure 12 showed the interaction between engine speed and fuel temperature on noise intensity, lower noise intensity rate $81.217 \mathrm{~dB}$ was recorded at speed of $1000 \mathrm{rpm}$ with fuel temperature at $40^{\circ} \mathrm{C}$, while the higher noise intensity rate $90.667 \mathrm{~dB}$ was recorded at engine speed of $2000 \mathrm{rpm}$ with fuel temperature $50^{\circ} \mathrm{C}$. It can be seen from fig 13 showed the effect of interaction between load and fuel temperature on noise intensity. It has a significant effect to achieve the lower noise intensity $83.333 \mathrm{~dB}$, at temperature $40^{\circ} \mathrm{C}$, without load . While the higher noise intensity reached $88.589 \mathrm{~dB}$ that was recorded at high fuel temperature $50^{\circ} \mathrm{C}$ with load. Figure 14 showed interaction between engine speeds with load. It has a significant effect on noise intensity to achieve the lowest rate $83.641 \mathrm{~dB}$, as engine running speed of $1000 \mathrm{rpm}$, without load .while with engine speed at 2000rpm registered higher noise intensity $90.160 \mathrm{~dB}$, with load.

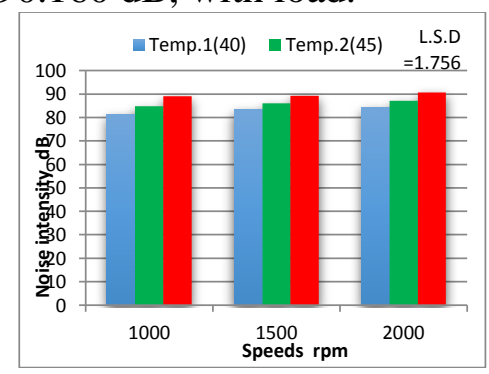

Fig.12. Effect of speed and load on noise intensity

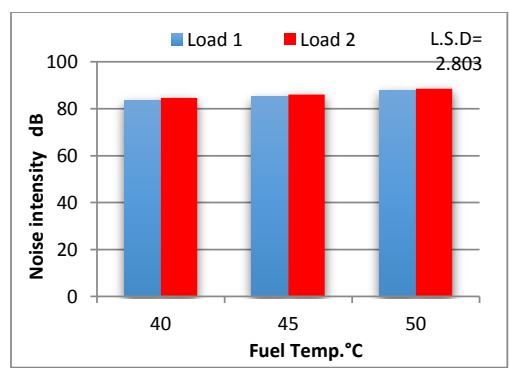

Fig. 13. Effect of FT and load on noise intensity

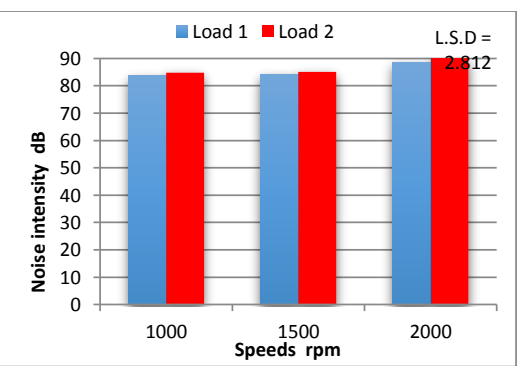

Fig.14. Effect of speed and load on noise intensity 
Fig. 15 showed the triple interaction between fuel temperatures, speeds and loads. Fuel at $50^{\circ} \mathrm{C}$ recorded highest rate $91.000 \mathrm{~dB}$ of noise intensity with load, at speed of $2000 \mathrm{rpm}$, while the lowest rate $80.000 \mathrm{~dB}$ of noise intensity was recorded at lowest engine speed of $1000 \mathrm{rpm}$ and fuel temperature at $40^{\circ} \mathrm{C}$ without load. It can be noticed that effect of fuel temperature has more influence than other factors.

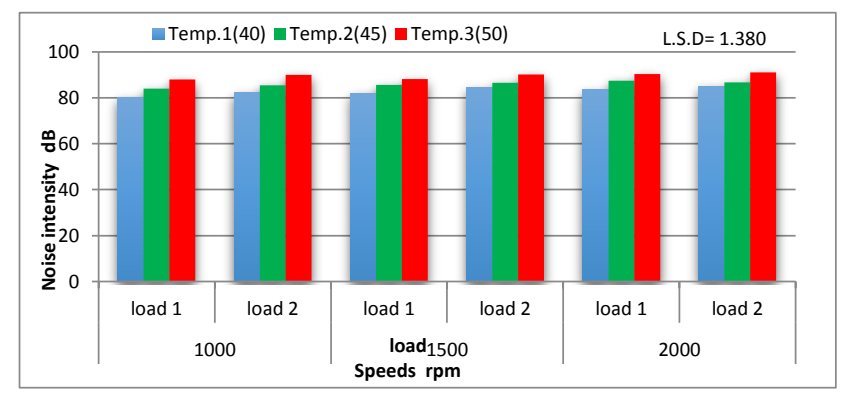

Fig.15. The effect of triple interaction between fuel temperature, Speed and load on noise intensity

\section{CONCLUSIONS}

1. The present work demonstrate the possibility of controlling fuel inlet temperature by using an apparatus connect with fuel supply line of diesel engine and test it at different fuel temperature ranging from $\left(40-50{ }^{\circ} \mathrm{C}\right)$;

2. Inlet fuel temperature have a vital role on fuel consumption, therefore fuel at temperature $40{ }^{\circ} \mathrm{C}$ recorded lower rate;

3. There is a positive significant effect of fuel temperature on most of engine performance indicators included FC, EGT, noise intensity;

4. Significant reduction rate in noise intensity was observed when fuel temperature at 40 ${ }^{\circ} \mathrm{C}$.

\section{REFERENCES}

Aworanti, O. A., Agarry, S. E., \& Ajani, A. O. (2012). A laboratory study of the effect of temperature on densities and viscosities of binary and ternary blends of soybean oil, soy biodiesel and petroleum diesel oil. Advances in Chemical Engineering and Science, 2(04), 444.

Chyo, T., Kanefsky, P., Armesto, C., Shah, A., \& Schoen, D. (2011). Diesel fuel cooling system and control strategy. U.S. Patent No. 8,006,675. Washington, DC: U.S. Patent and Trademark Office.

Mamat, R., Abdullah, N. R., Xu, H., Wyszynski, M. L., \& Tsolakis, A. (2009). Effect of fuel temperature on performance and emissions of a common rail diesel engine operating with rapeseed methyl ester (RME) (No. 2009-01-1896). SAE Technical Paper.

Mohanty, R. K. (2007) Internal Combustion Engines, Standard Book House. P: 468-501.

Oluwa Funmilayo (2012) A Laboratory Study of the Temperature on Densities and Viscosities of Binary and Ternary Blends of Soybean Oil , Soy Biodiesel and Petroleum Diesel Oil Advance in Chemical Engineering and Science, 2: 444-452.

Pawan, K. (2009) Significance of the ratio of exhaust temperature to coolant temperature and its effect on Various engine working parameters Proceeding of the world congress on engineering, Vol. II, London, UK. Pedley, J. F., Hiley, R. W., \& Hancock, R. A. (1989). Storage stability of petroleum-derived diesel fuel: 4. Synthesis of sediment precursor compounds and simulation of sediment formation using model systems. Fuel, 68(1), 27-31.

Rafidah, R. P. (2012) Influence of fuel temperature on a diesel engine performance operating with biodiesel blended. Journal of Mechanical Engineering and Sciences (JMES) 226-236.

Velmurugan, K., \& Gowthamn, S. (2012). Effect of cetane improver additives on emissions. International Journal of Modern Engineering Research, 2(5), 3372-3375. 